\title{
Nucleotide and Deduced Amino Acid Sequence of HBV Gene
}

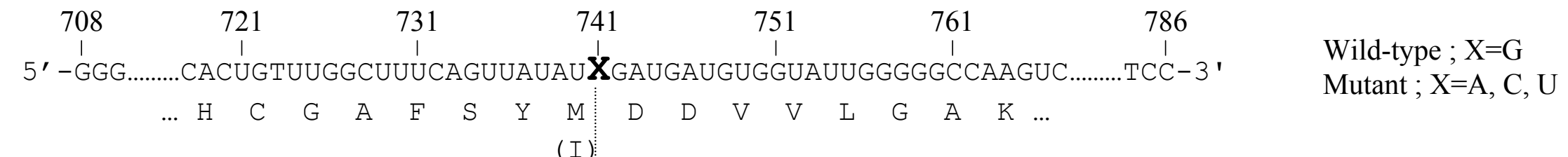

\section{Nucleotide Sequence of Probes}

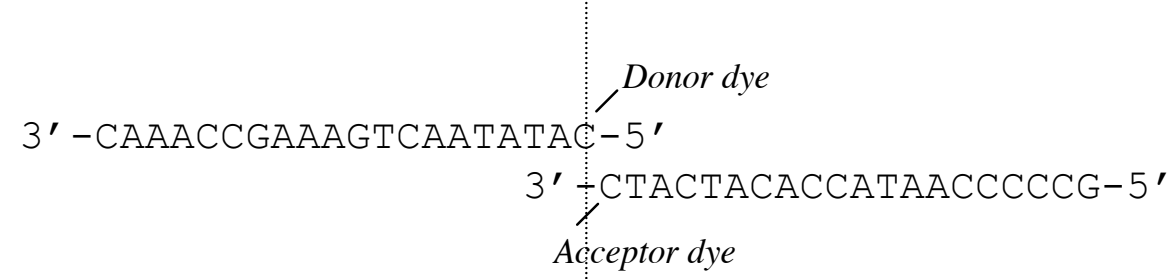

Probe combination Mismatch position (donor/acceptor)

$(722-741) /(742-761)$ $\mathrm{n}=1$ (ultimate)

$(723-742) /(743-762)$ $\mathrm{n}=2$ (penultimate) 
Preparation of purine-rich DNA template for in vitro transcription

5' -AtgAtCACtAAtACGACtCACtAtAgGgCACACACCCCTACGTACGAAAAGGG-3' $\longrightarrow$

$\longleftarrow$ 3'GGGGATGCATGCTTTTCCCTTTTGTAGACCCTTTCTCTGTAAAAATTTTT-5'

Pyrobest DNA polymerase

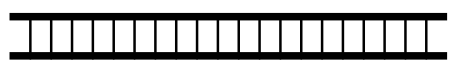

T7 RNA polymerase

RNA sample

FRAP assay for purine-rich model sequence

$$
\text { RNA purine-rich region }
$$

5' -GGGCACACACCCCTACGTACGAAAAGGGAAAACATCTGGGAAAGAGACATTTTTAAAAA-3'

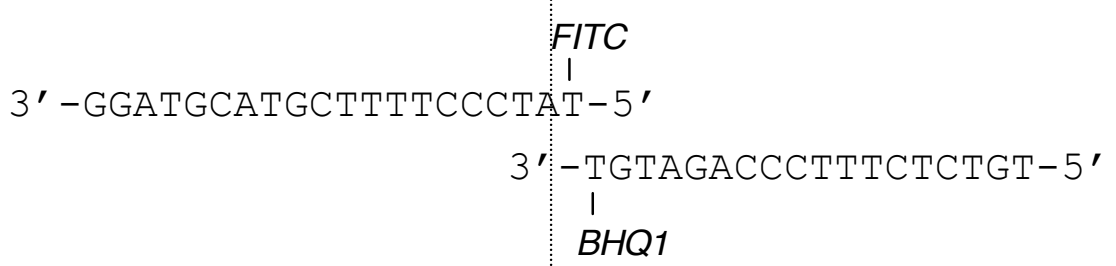

mismatch site

\section{Figure S2}

